\title{
Trace-Element Distribution on Sulfide Mineralization in Trento Province, NE Italy
}

\author{
Gianluca Bianchini ${ }^{1, *}$, Claudio Natali ${ }^{2}$, Paolo Ferretti ${ }^{3}$, Lara Casagrande ${ }^{4}$, Manuel Conedera 5 \\ and Chiara Marchina ${ }^{1}$ \\ 1 Dipartimento di Fisica e Scienze della Terra, Università degli Studi di Ferrara, Via Saragat 1, 44122 Ferrara, \\ Italy; mrcchr@unife.it \\ 2 Dipartimento di Scienze della Terra, Università degli Studi di Firenze, Via G. La Pira 4, 50121 Firenze, Italy; \\ claudio.natali@unifi.it \\ 3 MUSE-Museo delle Scienze di Trento, Corso del Lavoro e della Scienza 3, 38122 Trento, Italy; \\ paolo.ferretti@muse.it \\ 4 Ecomuseo Argentario, Via Cesare Battisti 1, 38045 Civezzano (TN), Italy; info@ecoargentario.it \\ 5 Freelance researcher, Via Ponte Alto 30/c, 32020 Rivamonte Agordino (BL), Italy; \\ manuelconedera@gmail.com \\ * Correspondence: bncglc@unife.it
}

Received: 25 October 2019; Accepted: 25 November 2019; Published: 28 November 2019

\begin{abstract}
Sulfide mineralization in the province of Trento (northeastern Italy) includes various mineral assemblages that are often silver-rich and have been exploited in different phases from the Middle Ages until the 20th century. This study investigates mineralized rocks from three historically important sites (Calisio mount, Erdemolo lake, and the locality of Cinque Valli), providing new analytical data (Inductively Coupled Plasma-Mass Spectrometry on bulk rocks, and Scanning Electron Microscopy on thin sections) that demonstrate that parageneses do not only include galena, chalcopyrite, and sphalerite but also accessory minerals, such as tetrahedrite, tennantite, acanthite, and sulfosalts (matildite/polybasite). This explains the high content of As (up to $278 \mathrm{ppm}$ ), Bi (up to $176 \mathrm{ppm}$ ), and $\mathrm{Sb}$ (up to $691 \mathrm{ppm}$ ) that are associated with $\mathrm{Pb}-\mathrm{Cu}-\mathrm{Zn}$ mineralization. Notably, trace-element ratios indicate that, although closely associated from a geographical point of view, the studied sites are not genetically related and have to be referred to in distinct mineralization events, possibly induced by three diverse magmatic and hydrothermal phases that occurred in the Variscan post-orogenic setting. Besides geological and petrogenetic reconstruction, the new data outline potential geochemical risks, as they reveal a high concentration of elements characterized by marked toxicity that can be transferred into the local soil and water. Therefore, future studies should be devoted to better investigating the metal distribution in the surroundings of ancient mining sites and their geochemical behavior during the weathering processes.
\end{abstract}

Keywords: sulfide mineralization; Trento; trace-elements; accessory minerals

\section{Introduction}

Sulfide-bearing rocks in the province of Trento (Figure 1) in northeastern Italy include Ag-rich $\mathrm{Pb}-\mathrm{Zn}-\mathrm{Cu}$ mineralization. Minerals were extracted at several phases since the Middle Ages, and the activity continued until 1964, when the last mine of the Province (Calceranica) closed. Previous studies on local mineralization [1] generally associated $\mathrm{Ag}$ to galena, but detailed geochemical-mineralogical investigations [2-8] are still lacking in the literature. The purpose of the current contribution is to provide new analytical data (Inductively Coupled Plasma-Mass Spectrometry on bulk rocks and Scanning Electron Microscopy on polished thin sections) on mineralized rocks from three distinct sites, namely, 
the Calisio mount, known for galena concentration in Early Triassic carbonate rocks, Erdemolo lake, and Cinque Valli surroundings, both known for the mineralization of mixed (galena-chalcopyrite-sphalerite) sulfides in sialic veins closely related to Permian magmatic rocks. The data offer insight into genetic conditions and also into potential environmental pollution by heavy metals.

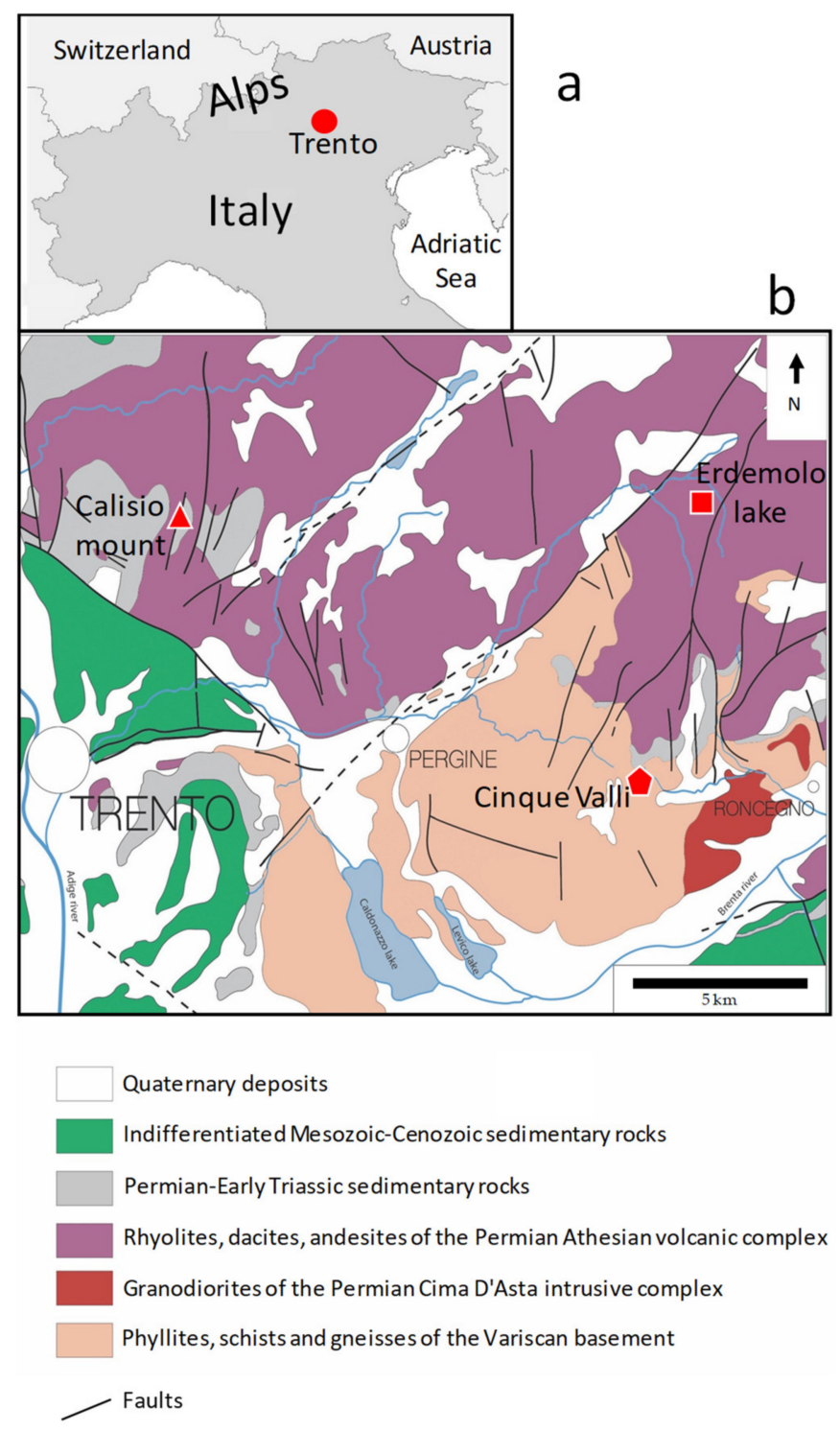

Figure 1. Simplified (a) geographic and (b) geological sketches of studied area located in the province of Trento (NE Italy). Symbols denote localities where mineralized rocks were sampled. Red triangle, Calisio mount; red diamond, Erdemolo lake; red pentagon, Cinque Valli site. Geological information was retrieved by map of lithology and structural elements of Trento.

\section{Materials and Methods}

\subsection{Geological Outlines}

The investigated sites are located in the northeastern sector of the province of Trento (Figure 1), geologically pertaining to the South-Alpine domain. The outcropping crystalline basement consists of metamorphic rocks (phyllades and mica-schists) and igneous granitic (s.l.) intrusions formed during the Variscan orogeny $[9,10]$. The basement is covered by Permian volcanics consisting of ignimbrites, mainly rhyolitic in composition, of the Athesian Volcanic Group [11,12], and by Triassic sedimentary rocks [13,14], sometimes crosscut by Early Triassic basic dykes [15]. 
Sulfide deposits are widespread in the area [16,17], as attested by massive veins (dominated by pyrite) within the Variscan metamorphic basement (as observed in Calceranica) that indicate that the pre-metamorphic volcano-sedimentary sequence (i.e., sedimentary protholites) were already enriched in sulfur, possibly in relation to exhalative deposition induced by ore-bearing hydrothermal fluids into an Early Palaeozoic marine basin.

The post-Variscan (Permian) magmatic episodes, characterized by calcalkaline products, and the associated hydrothermal processes remobilized sulfur and metals with the formation of mineralized veins and metasomatic aureolas in the surrounding rock matrices. These occurrences are observed within the lower part of the Athesian Volcanic Group (as observed at the Erdemolo lake site [18]) or at the contact between intrusive igneous rocks and the metamorphic basement (as observed at the Cinque Valli site [19]). Early Triassic magmatism, attested by dykes having shoshonite affinity, and associated hydrothermal fluids induced further remobilization and additional ore deposits within the sedimentary sequence [1], as observed in the Werfen formation outcropping at Calisio mount [15].

\subsection{Hand-Specimen Description}

Photographs of the investigated hand specimens are shown in Figure 2. Mineralized rocks from the Calisio mount are represented by dark oolitic carbonates, locally crosscut by sulfide-bearing veinlets of gray color (see sample MGC2 in Figure 2a). Some rocks from Erdemolo lake have a porphyric texture in which large (up to $3-4 \mathrm{~cm}$ ) aggregates of quartz and feldspar are surrounded by a greenish matrix including millimetric sulfide crystals (Sample MGE3 in Figure 2b), whereas other samples appear almost totally constituted by sulfides (Sample MGE5 in Figure 2c). Some rocks from Cinque Valli site have equigranular texture with comparable abundance of silicates (mainly quartz and feldspar) and sulfides (Sample MGV5), whereas others are totally dominated by sulfides, mainly represented by brown sphalerite and grey galena (Sample MGV2 in Figure 2d). The assumption is that (1) rocks from the Calisio mount were mineralized by a fluid that shortly post-dated the deposition of calcareous rocks; (2) rocks from Erdemolo lake are representative of a metasomatic process in which previous magmatic parageneses were affected by propylitic processes due to late-stage magmatic/hydrothermal fluids; and (3) rocks from Cinque Valli are representative of hydrothermal veins crosscutting the basement in a close relationship with magmatic intrusion.


Figure 2. Hand-specimen photographs of studied mineralized rocks. (a) Sample MGC2 from Calisio mount, where brown oolitic carbonate matrix is crosscut by sulfide (mainly galena) veinlet; (b) sample MGE3 from Erdemolo lake characterized by porphyric texture with quartz and feldspar aggregates within a greenish matrix containing millimetric sulfide crystals; (c) sample MGE5 from Erdemolo lake constituted by prevalent sulfide (mainly yellow chalcopyrite); (d) sample MGV2 from Cinque Valli site mainly constituted by sulfide (with prevalent brown sphalerite and grey galena). 


\subsection{Analytical Methods}

Bulk rock geochemical analyses were carried out by Inductively Coupled Plasma Mass Spectrometry (ICP-MS) after dissolution. Bulk rock powders $(0.15 \mathrm{~g})$ of 7 samples were digested with $\mathrm{HF}-\mathrm{HNO}_{3}$ on a hot plate. Dissolved samples were dried out and then redissolved in ultrapure water obtained from a Milli-Q purifier system (Direct-Q UV, Millipore, Burlington, MA, USA). Analyses were carried out using a $X$ series Thermo-Scientific spectrometer (Thermo, Bremen, Germany). Specific amounts of Rh and Re were added to the analyzed solutions as an internal standard in order to correct the instrument drift. Accuracy and precision, based on replicated analyses of samples and standards were $10 \%$ for all elements, well above the detection limit. Bulk-rock analyses were integrated with an in situ investigation carried out by electron microscope (SEM EVO-40 XVP; Carl Zeiss, Oberkochen, Germany) on polished thin sections.

\section{Results}

\subsection{Bulk Rock Analyses}

Bulk rock analyses (expressed in ppm) of mineralized rocks from the investigated areas, carried out by ICP-MS, are reported in Table 1. Ca (from 28.85 to $32.15 \mathrm{wt} \%$ ), $\mathrm{Mg}$ (from 8.56 to $6.76 \mathrm{wt} \%$ ), Sr (from 63 to $210 \mathrm{ppm}$ ), Ba (from 16 to $111 \mathrm{ppm}$ ), and Mn (from 6906 to 13,340 ppm) are comparatively high in rocks from the Calisio mount with respect to rocks from the Erdemolo lake and Cinque Valli sites, indicating their carbonate and silicate nature, respectively. Considering silicate-bearing rocks, $\mathrm{Al}$ (up to $2.34 \mathrm{wt} \%$ ), $\mathrm{Ca}$ (up to $2.96 \mathrm{wt} \%$ ), and $\mathrm{Mg}$ (up to $0.41 \mathrm{wt} \%$ ) were enriched in the silicate rocks of Erdemolo lake with respect to those of Cinque Valli, indicating that the silicate fraction contained a significant amount of feldspar (in large white aggregates) and chlorite/amphibole, plausibly concentrated in the greenish matrix. Rocks from the Erdemolo lake also displayed comparative enrichment in P (up to $194 \mathrm{ppm}$ ), Ti (up to $220 \mathrm{ppm}$ ), V (up to $17 \mathrm{ppm}$ ), and Sc (up to $5.2 \mathrm{ppm}$ ), as well as Se (up to $61 \mathrm{ppm}$ ) and Te (up to $0.8 \mathrm{ppm}$ ). This suggests the presence of accessory minerals, such as apatite and oxides, as well as isomorphous substitution between $\mathrm{S}$ and Se-Te [20-22].

Chalcophile elements of the Calisio mount were dominated by $\mathrm{Pb}$ (up to $137,048 \mathrm{ppm}$ ), clearly indicating that they mainly contain galena. Rocks from Erdemolo lake could be dominated by $\mathrm{Pb}$ (up to 101,981 ppm) or by $\mathrm{Cu}$ (up to 191,530 ppm), indicating the prevalence of galena or chalcopyrite. Sphalerite was prevalent only in samples from Cinque Valli that showed high concentration (up to $271,351 \mathrm{ppm}$ ) of $\mathrm{Zn}$. The concentration ranges of $\mathrm{Ag}$ in the investigated rocks varied between 50 and 142 ppm at the Calisio mount, 51 and 311 ppm at Erdemolo lake, and 69 and 118 ppm at Cinque Valli. Considering that $\mathrm{Ag}$ is generally associated with galena, we calculated the $\mathrm{kg}$ of $\mathrm{Ag}$ for each rock for a ton of galena; it appeared that the grade of $\mathrm{Ag}$ was up to $2.2 \mathrm{~kg} / \mathrm{t}$ at the Calisio mount, up to $3.1 \mathrm{~kg} / \mathrm{t}$ at the Erdemolo lake, and up to $0.4 \mathrm{~kg} / \mathrm{t}$ at Cinque Valli.

The new analyses also highlighted a remarkable concentration of other elements, such as As that was up to $278 \mathrm{ppm}$ in the Calisio mount rocks and up to $35 \mathrm{ppm}$ in the Erdemolo lake rocks. $\mathrm{Sb}$ was unexpectedly high in rocks from the Calisio mount (up to $670 \mathrm{ppm}$ ) and those from Cinque Valli (up to $691 \mathrm{ppm}$ ). Cd was also very high in rocks from the Erdemolo lake (up to $409 \mathrm{ppm}$ ) and Cinque Valli (up to $737 \mathrm{ppm}$ ). Further anomalies are represented by the very high concentrations of $\mathrm{Bi}$ (up to $176 \mathrm{ppm}$ ) and Sn (up to $111 \mathrm{ppm}$ ) that were recorded in rocks from the Erdemolo lake, and the high concentration of $\mathrm{Ga}$ (up to $61 \mathrm{ppm}$ ) that was typical of rocks from Cinque Valli. Significant amounts (up to $2.7 \mathrm{ppm}$ ) of Mo were recorded in rocks from Cinque Valli. These data suggest that the parageneses of these mineralizations are more complex than what is generally known, and that additional accessory minerals have to be present with common sulfides, such as galena, chalcopyrite, and sphalerite. Element ratios provide additional clues to distinguish ores from the distinct sites, as they give the signature of causative metasomatic agents. Accordingly, Figure 3, where K/Na vs. $\mathrm{Fe} / \mathrm{Mn}, \mathrm{Li} / \mathrm{Rb}$ vs. $\mathrm{Sr} / \mathrm{Ba}, \mathrm{Sb} / \mathrm{Te}$ vs. As/Se, and $\mathrm{Bi} / \mathrm{Tl}$ vs. $\mathrm{Cd} / \mathrm{Sn}$ diagrams are reported, denotes specific (scarcely overlapped) fields for the distinct mining sites. 
Table 1. ICP-MS analyses (expressed in ppm) of mineralized rocks from Calisio mount (MGC), Erdemolo lake (MGE), and Cinque Valli (MGV).

\begin{tabular}{|c|c|c|c|c|c|c|c|}
\hline \multirow{2}{*}{$\begin{array}{c}\text { Analyzed } \\
\text { Element }\end{array}$} & \multicolumn{2}{|c|}{ Calisio Mount } & \multicolumn{3}{|c|}{ Erdemolo Lake } & \multicolumn{2}{|c|}{ Cinque Valli } \\
\hline & MGC1 & MGC2 & MGE1 & MGE3 & MGE5 & MGV2 & MGV3 \\
\hline $\mathrm{Ca}$ & 288,513 & 321,530 & 7804 & 29,572 & 509 & 140 & 2005 \\
\hline $\mathrm{Mg}$ & 85,595 & 67,562 & 2271 & 3242 & 4076 & 45.8 & 684 \\
\hline $\mathrm{Al}$ & 1891 & 618 & 16,143 & 19,264 & 23,388 & 995 & 4679 \\
\hline $\mathrm{Na}$ & 114 & 180 & 44.1 & 116 & 26.2 & 120 & 3838 \\
\hline K & 308 & 158 & 497 & 1173 & 1177 & 283 & 2194 \\
\hline $\mathrm{Li}$ & 56.2 & 19.4 & 51.5 & 182 & 47.8 & 30.7 & 48.4 \\
\hline $\mathrm{Rb}$ & 1.83 & 0.93 & 3.03 & 8.71 & 3.62 & 2.61 & 14.3 \\
\hline $\mathrm{Sr}$ & 62.8 & 210 & 2.37 & 7.13 & 1.06 & 1.62 & 5.39 \\
\hline $\mathrm{Ba}$ & 16.0 & 111 & n.d. & 4.71 & 7.04 & 0.49 & 8.58 \\
\hline $\mathrm{P}$ & 44.9 & 41.1 & 65.8 & 81.4 & 194 & 19.1 & 25.0 \\
\hline B & 28.7 & 24.3 & 13.4 & 31.2 & n.d. & 0.86 & 9.88 \\
\hline $\mathrm{Be}$ & 0.29 & 0.25 & 0.26 & 0.48 & 0.11 & 0.30 & 0.60 \\
\hline $\mathrm{Fe}$ & 21,098 & 18,607 & 79,475 & 41,450 & 303,616 & 3402 & 3059 \\
\hline $\mathrm{Mn}$ & 13,340 & 6906 & 1435 & 2500 & 2709 & 12.6 & 9.08 \\
\hline $\mathrm{Ti}$ & 38.6 & 16.1 & 74.2 & 92.0 & 220 & 2.78 & 10.1 \\
\hline $\mathrm{Cu}$ & 1376 & 791 & 24,434 & 15,398 & 191,530 & 1132 & 374 \\
\hline $\mathrm{Zn}$ & 260 & 259 & 90,692 & 24,671 & 793 & 232,752 & 271,351 \\
\hline $\mathrm{Pb}$ & 56,276 & 137,048 & 101,981 & 61,735 & 1249 & 74,273 & 38,476 \\
\hline $\mathrm{Ag}$ & 142 & 50.7 & 64.0 & 311.4 & 51.7 & 118 & 69.3 \\
\hline $\mathrm{Sb}$ & 602 & 670 & 38.1 & 30.7 & 38.0 & 691 & 194 \\
\hline $\mathrm{Bi}$ & 0.25 & 0.35 & 176 & 47.2 & 59.1 & 1.40 & 0.31 \\
\hline As & 278 & 86.7 & 34.8 & 5.95 & 42.7 & 1.78 & 3.14 \\
\hline $\mathrm{Cd}$ & 7.2 & 4.2 & 409 & 150 & 5.06 & 648 & 737 \\
\hline Sn & 0.58 & 0.48 & 61.2 & 42.1 & 111 & 4.47 & 2.16 \\
\hline $\mathrm{Ga}$ & 0.47 & 2.03 & 2.30 & 3.09 & 4.81 & 59.0 & 61.0 \\
\hline Se & 0.69 & 0.32 & 61.0 & 25.0 & 52.2 & 2.86 & 2.74 \\
\hline $\mathrm{Te}$ & 0.05 & 0.06 & 0.83 & 0.31 & 0.17 & 0.08 & 0.10 \\
\hline Sc & 1.23 & 0.44 & 1.21 & 3.34 & 5.23 & n.d. & n.d. \\
\hline $\mathrm{V}$ & 1.22 & 1.23 & 5.22 & 9.85 & 17.1 & n.d. & 2.24 \\
\hline $\mathrm{Cr}$ & 1.59 & 0.94 & 3.17 & 4.37 & 8.87 & 0.35 & 0.57 \\
\hline Co & 5.23 & 10.4 & 10.7 & 6.06 & 17.0 & 21.2 & 24.4 \\
\hline $\mathrm{Ni}$ & 73.0 & 75.9 & 2.89 & 8.63 & 2.48 & 0.44 & 1.46 \\
\hline Mo & 0.02 & 0.68 & 0.21 & 0.42 & 1.69 & 1.95 & 2.65 \\
\hline $\mathrm{Tl}$ & 0.28 & 0.59 & 0.17 & 0.08 & n.d. & 0.22 & 0.06 \\
\hline $\mathrm{U}$ & 0.60 & 0.76 & 0.08 & 0.12 & 0.25 & n.d. & 0.04 \\
\hline
\end{tabular}

\subsection{Results of In Situ (SEM) Analyses}

Scanning electron microscopy (SEM) back-scattered images are reported in Figures 4 and 5, and EDS, semi-quantitative analyses are reported in Tables 2 and 3. 

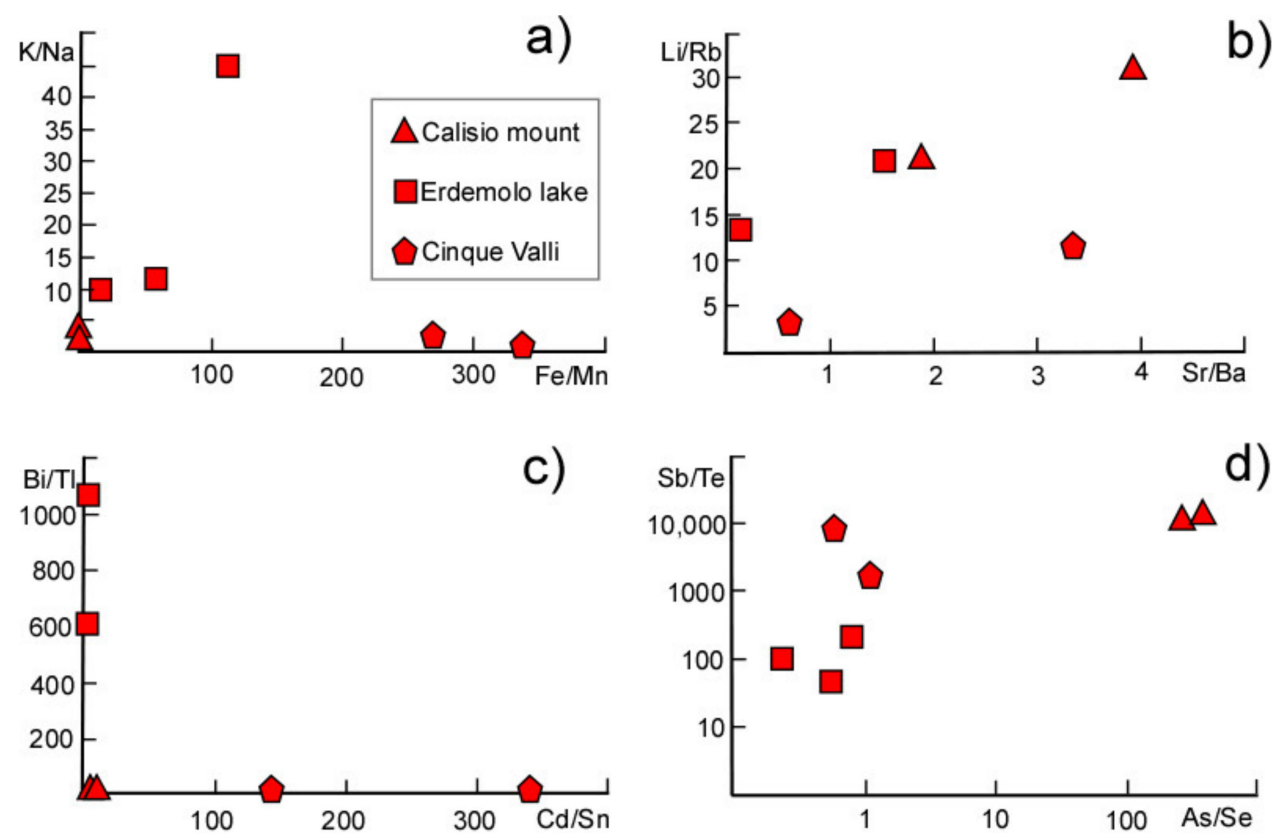

Figure 3. Binary diagrams showing elemental ratios can be discriminant of mineralized rocks from the Calisio mount, Erdemolo lake, and Cinque Valli. (a) K/Na vs. Fe/Mn, (b) Li/Rb vs. Sr/Ba, (c) Bi/Tl vs. $\mathrm{Cd} / \mathrm{Sn},(\mathbf{d}) \mathrm{Sb} / \mathrm{Te}$ vs. As/Se.
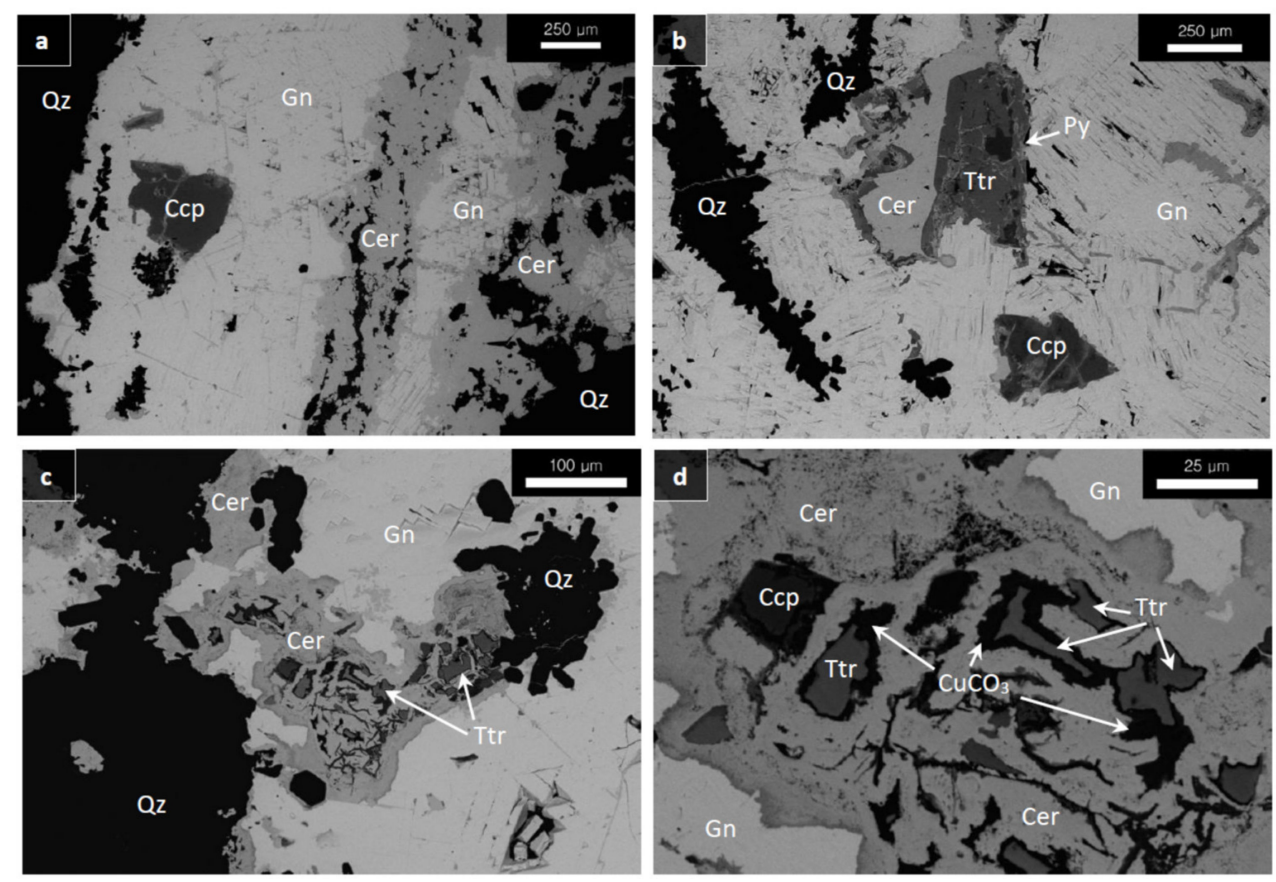

Figure 4. Back-scattered scanning electron microscopy (SEM) images of mineralized rocks from Calisio mount. Note that mineralization is not solely composed by galena, and that the paragenesis is remarkably more complex. Abbreviations: $\mathrm{Qz}=$ quartz, $\mathrm{Gn}=$ galena, $\mathrm{Ttr}=$ tetrahedrite, $\mathrm{Ccp}=$ chalcopyrite, Cer $=$ cerussite, $\mathrm{Py}=$ pyrite, $\mathrm{CuCO}_{3}=$ copper carbonate. (a) shows that the mineralized veinlet, mainly composed by $\mathrm{Gn}$, also contains minor Qz and Ccp, as well as secondary minerals such as Cer; (b) shows that Trd is also present in the mineral association; (c) and (d) emphasize that Trd is altered and resorbed, indicating that this mineral is unstable in supergene condition. 

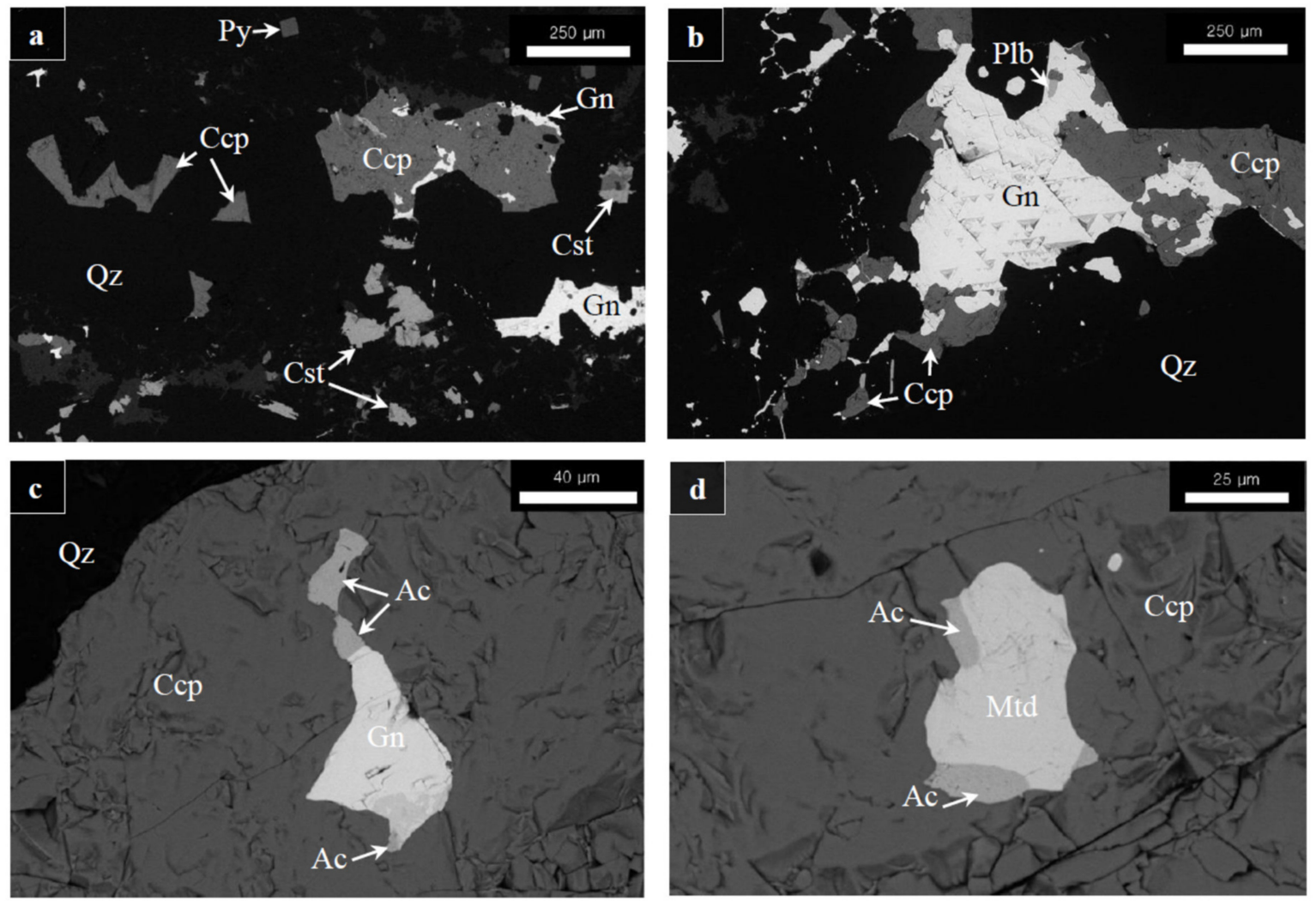

Figure 5. Back-scattered scanning electron microscopy (SEM) images of mineralized rocks from the Erdemolo lake. Note that mineralization is not solely composed by galena and chalcopyrite, and that the paragenesis is remarkably more complex. Abbreviations: $\mathrm{Qz}=$ quartz, $\mathrm{Gn}=$ galena, $\mathrm{Ttr}=$ tetrahedrite, Tnt $=$ tennantite, $\mathrm{Ccp}=$ chalcopyrite, $\mathrm{Py}=$ pyrite, $\mathrm{Ac}=$ acanthite, $\mathrm{Cst}=$ cassiterite, $\mathrm{Plb}=$ polybasite, Mtd = matildite. (a) shows the intimate association of Ccp, Gn, Py, Cst, Qz; (b) shows the presence of $\mathrm{Plb}$; (c) shows the presence of Ac; (d) shows the presence of Mtd.

Table 2. SEM (EDS) semi-quantitative analyses (wt \%) of minerals at Calisio mount; analyses were normalized to $100 \%$.

\begin{tabular}{|c|c|c|c|c|c|c|c|c|c|c|}
\hline \multirow{2}{*}{$\frac{\mathbf{w t} \%}{\mathrm{~S}}$} & \multicolumn{5}{|c|}{ Galena } & \multirow{2}{*}{$\frac{\text { wt } \%}{C}$} & \multicolumn{4}{|c|}{ Cerussite } \\
\hline & 13.1 & $12.65 \quad 12.55$ & 12.71 & 12.37 & 12.35 & & 8.48 & 9.46 & $10.03 \quad 10.02$ & 8.99 \\
\hline $\mathrm{Ag}$ & 0.46 & - & - & - & 0.20 & $\mathrm{O}$ & 27.53 & 29.88 & $31.25 \quad 31.22$ & 28.77 \\
\hline $\mathrm{Pb}$ & 86.44 & $87.35 \quad 87.45$ & 87.29 & 87.63 & 87.45 & $\mathrm{~Pb}$ & 63.99 & 60.66 & $58.73 \quad 58.76$ & 62.24 \\
\hline Total & 100 & 100 & 100 & 100 & 100 & Total & 100 & 100 & 100 & 100 \\
\hline wt $\%$ & \multicolumn{10}{|c|}{ Tetrahedrite-Tennantite } \\
\hline$S$ & 25.45 & 24.62 & 23.03 & 25.9 & 24.88 & 23.55 & 23.15 & 24.82 & 25.02 & 25.93 \\
\hline $\mathrm{Fe}$ & 0.38 & 1.26 & 0.61 & 0.37 & 0.48 & 0.51 & 0.51 & - & - & - \\
\hline $\mathrm{Cu}$ & 31.87 & 32.09 & 27.53 & 31.58 & 31.29 & 26.19 & 27.11 & 31.17 & 30.65 & 31.42 \\
\hline $\mathrm{Zn}$ & 6.41 & 5.86 & 5.63 & 6.56 & 6.11 & 5.64 & 6.19 & 6.34 & 5.72 & 6.44 \\
\hline As & 7.60 & 10.55 & 3.82 & 15.91 & 14.53 & - & 4.55 & 7.53 & 11.86 & 8.74 \\
\hline $\mathrm{Ag}$ & 2.66 & 1.09 & 4.98 & - & 0.97 & 8.04 & 4.65 & 2.33 & 2.32 & 3.73 \\
\hline $\mathrm{Sb}$ & 15.65 & 9.9 & 19.11 & 3.35 & 4.74 & 22.05 & 18.56 & 16.04 & 8.46 & 13.53 \\
\hline $\mathrm{Pb}$ & 9.97 & 14.63 & 15.29 & 16.33 & 17.00 & 14.02 & 15.29 & 11.77 & 15.97 & 10.21 \\
\hline Total & 100 & 100 & 100 & 100 & 100 & 100 & 100 & 100 & 100 & 100 \\
\hline wt $\%$ & \multicolumn{10}{|c|}{ Chalcopyrite } \\
\hline$S$ & 38.15 & 38.04 & 38.36 & & 7.59 & 41.65 & 39.37 & 40.02 & 38.19 & 40.60 \\
\hline $\mathrm{Fe}$ & 28.81 & 28.64 & 28.24 & & 9.46 & 27.27 & 26.81 & 27.46 & 28.38 & 27.79 \\
\hline $\mathrm{Cu}$ & 33.04 & 33.32 & 33.40 & & 2.95 & 31.09 & 33.83 & 32.52 & 33.43 & 31.62 \\
\hline Total & 100 & 100 & 100 & & 100 & 100 & 100 & 100 & 100 & 100 \\
\hline
\end{tabular}


Table 3. SEM (EDS) semi-quantitative analyses (wt \%) of minerals at Erdemolo lake; analyses were normalized to $100 \%$.

\begin{tabular}{|c|c|c|c|c|c|c|c|c|c|c|c|}
\hline wt $\%$ & \multicolumn{11}{|c|}{ Galena } \\
\hline$S$ & 13.13 & 13.17 & 13.42 & 13.62 & 13.37 & 13.48 & 13.27 & 12.81 & 13.19 & 12.94 & 15.31 \\
\hline $\mathrm{Ag}$ & 0.27 & 0.61 & 0.44 & 1.17 & 1.34 & 1.84 & 1.90 & 0.25 & - & 0.29 & 0.11 \\
\hline $\mathrm{Pb}$ & 86.6 & 86.23 & 86.14 & 85.21 & 85.29 & 84.68 & 84.83 & 86.93 & 86.81 & 86.77 & 84.57 \\
\hline Total & 100 & 100 & 100 & 100 & 100 & 100 & 100 & 100 & 100 & 100 & 100 \\
\hline wt \% & \multicolumn{2}{|c|}{ Chalcopyrite } & wt \% & \multicolumn{3}{|c|}{ Sphalerite } & wt \% & \multicolumn{4}{|c|}{ Acanthite } \\
\hline$S$ & 35.74 & 35.41 & $S$ & 36.37 & 30.16 & 38.09 & $S$ & 13.96 & 17.92 & 13.77 & 16.99 \\
\hline $\mathrm{Fe}$ & 30.64 & 29.65 & $\mathrm{Fe}$ & 0.93 & 2.34 & 1.29 & $\mathrm{Ag}$ & 86.04 & 82.08 & 86.23 & 83.01 \\
\hline $\mathrm{Cu}$ & 33.62 & 34.95 & $\mathrm{Zn}$ & 62.7 & 67.5 & 60.63 & Total & 100 & 100 & 100 & 100 \\
\hline Total & 100 & 100 & Total & 100 & 100 & 100 & & & & & \\
\hline wt \% & \multicolumn{11}{|c|}{ Sulfosalts } \\
\hline$S$ & \multicolumn{3}{|c|}{19.71} & \multicolumn{3}{|c|}{21.11} & \multicolumn{2}{|c|}{20.99} & \multicolumn{3}{|c|}{17.05} \\
\hline $\mathrm{Cu}$ & \multicolumn{3}{|c|}{-} & \multicolumn{3}{|c|}{-} & \multicolumn{2}{|l|}{-} & \multicolumn{3}{|c|}{3.52} \\
\hline $\mathrm{Ag}$ & \multicolumn{3}{|c|}{22.57} & \multicolumn{3}{|c|}{29.66} & \multicolumn{2}{|c|}{29.3} & \multicolumn{3}{|c|}{72.37} \\
\hline $\mathrm{Pb}$ & \multicolumn{3}{|c|}{21.95} & \multicolumn{3}{|c|}{-} & \multicolumn{2}{|l|}{-} & \multicolumn{3}{|c|}{-} \\
\hline $\mathrm{Sb}$ & \multicolumn{3}{|c|}{-} & \multicolumn{3}{|c|}{-} & \multicolumn{2}{|l|}{-} & \multicolumn{3}{|c|}{7.06} \\
\hline $\mathrm{Bi}$ & \multicolumn{3}{|c|}{35.77} & \multicolumn{3}{|c|}{49.24} & \multicolumn{2}{|c|}{49.71} & \multicolumn{3}{|c|}{-} \\
\hline Total & \multicolumn{2}{|r|}{100} & & \multicolumn{2}{|c|}{100} & & \multicolumn{2}{|c|}{100} & \multicolumn{3}{|c|}{100} \\
\hline
\end{tabular}

The data confirmed the existence of complex mineralogical associations, so far not described with recent analytical data in the province. In rocks from the Calisio mount, silver did not only appear contained in the prevalent galena (that contain up to $0.5 \mathrm{wt} \% \mathrm{Ag}$ ), but was concentrated in tetrahedrite (up to $8 \mathrm{wt} \% \mathrm{Ag}$ ), a mineral that contains up to $22.7 \mathrm{wt} \%$ of $\mathrm{Sb}$. An additional mineral that was recorded in rocks from Calisio mount is tennantite, which contains up to $12.7 \mathrm{wt} \%$ As, thus explaining the very high concentration recorded by bulk rock analyses. Tetrahedrite and tennantite formed solid solutions showing continuous variation in the $\mathrm{Sb} / \mathrm{As}$ vs $\mathrm{Ag} / \mathrm{Cu}$ diagram of Figure 6. Notably, tetrahedrite and tennantite are often surrounded by cerussite or copper carbonate, indicating that they are easily affected by alteration (oxidation) in supergene condition [23].

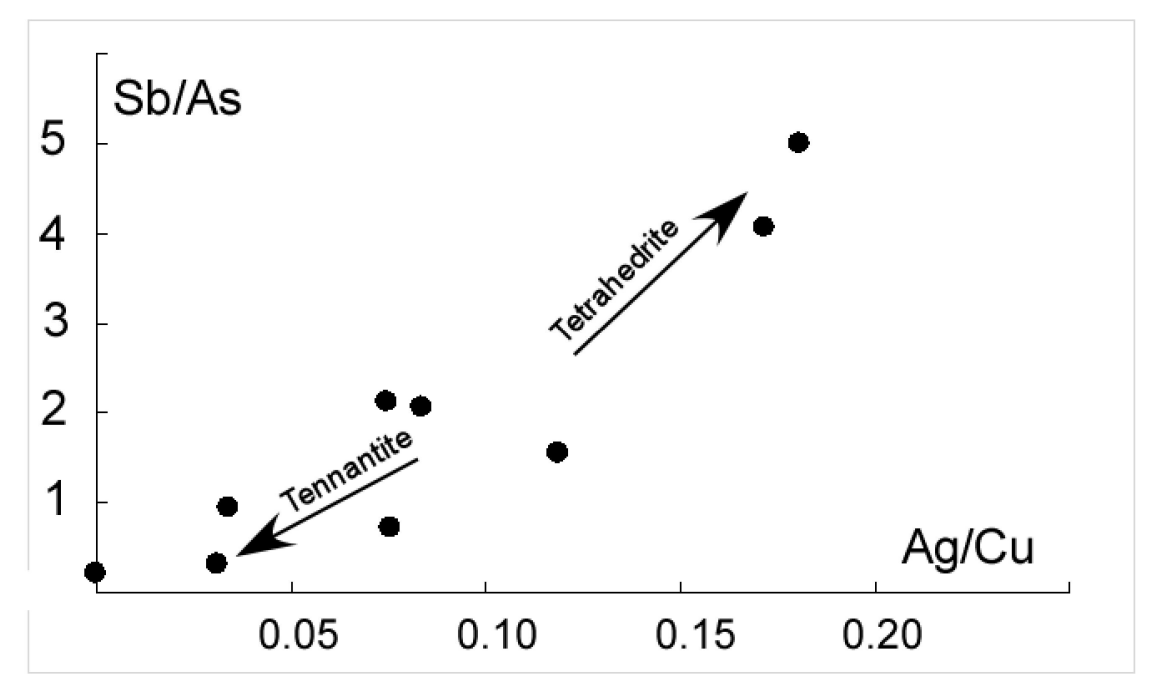

Figure 6. $\mathrm{Sb} / \mathrm{As}$ vs. $\mathrm{Ag} / \mathrm{Cu}$ interdependence in the tetrahedrite-tennantite series recorded in mineralized rocks from Calisio mount.

In rocks from the Erdemolo lake, where galena (containing Ag up to $1.9 \mathrm{wt} \%$ ) and chalcopyrite are dominant, we recorded other peculiar minerals, such as acanthite, i.e., $\mathrm{Ag}_{2} \mathrm{~S}$ ( $\mathrm{Ag}$ up to $66 \mathrm{wt} \%$ ) and matildite/polybasite that are $\mathrm{Ag}-\mathrm{Bi}-\mathrm{Sb}$ sulfosalts. Among oxides, cassiterite was observed, and 
coherently recent literature data [24] indicate that this mineral can host other trace elements that are comparatively enriched in Erdemolo rocks such as Ti, V, and Sc.

In rocks from Cinque Valli, preliminary analyses only recorded principal sulfides sphalerite and galena (containing Ag up to $0.2 \mathrm{wt} \%$ ); in these rocks, the anomalous content of $\mathrm{Cd}, \mathrm{Mo}$, Ga could be hosted in sphalerite as observed by recent researches $[2,8]$, and further investigation is needed to constrain this hypothesis.

\section{Discussion}

The investigated sulfide mineralizations are hydrothermal deposits induced by fluids, plausibly related to magmatic phases. Although geographically concentrated within a small area, the trace-element data indicate that mineralization events were distinct and independent. The Cinque Valli rocks were mineralized in connection with the intrusion of calcalkaline granodiorites into the metamorphic basement, and those of Erdemolo lake were mineralized in connection with the emplacement of calcalkaline volcanic rocks, ranging in composition between andesites and rhyolites.

We speculated that mineralization from the Calisio mount, although hosted in sedimentary rocks, is also associated with distal volcanic activity, since coeval shoshonitic dykes were discovered in the surroundings (ca. $10 \mathrm{~km}$ from the mineralized zone [15]). However, although independent, these magmatic phases belong to the same geodynamic post-orogenic framework, as they follow Variscan plate convergence, subduction, and continental collision. In this scenario, mantle sources were variously metasomatized by subduction components that enriched the derived magmas in volatiles (including sulfur) and chalcophile elements, which ultimately released mineralizing fluids in the upper crust [25].

Silver is often associated with galena, sometimes containing up to $1.9 \mathrm{wt} \% \mathrm{Ag}$. These values are high compared with ordinary galena composition [26], and are recorded in few ore deposits, where tetrahedrite-tennantite (known as minerals of the fahlore group) crystals having notable silver content (known as freibergite) were also observed ([27] and references therein). The observed high concentration of silver in galena can be explained with the simultaneous enrichment of antimony and/or bismuth because silver can be accommodated in galena as result of coupled substitution with $\mathrm{Ag}+\mathrm{Sb}$ and/or $\mathrm{Ag}+\mathrm{Bi}$ for $2 \mathrm{~Pb}$ atoms [28,29]; however, this elemental substitution of $\mathrm{Pb}$ with $\mathrm{Ag}(\mathrm{Sb}$, $\mathrm{Bi}$ ) is inhibited at low temperatures (below $300^{\circ} \mathrm{C}[29]$ ).

The record of tetrahedrite-tennantite within the investigated sulfides at the Calisio mount is therefore coherent with the observed wide spectrum of trace elements such as $\mathrm{Ag}$, $\mathrm{As}, \mathrm{Bi}, \mathrm{Sb}$, and it can be stated that tetrahedrite-tennantite are sulfide analog of amphiboles, suitable for reciprocal solutions [30-32]. The study of other mineralized areas characterized by significant zoning reveal that Ag-rich minerals of this series generally crystallize in epigenetic conditions from evolved (fractionated) hydrothermal fluids that progressively cooled when migrating from the source zone, which is often related with the emplacement of magmatic bodies [33-35]. Accordingly, fluid-inclusion studies on these minerals generally indicate genesis by hydrothermal fluids at formation temperatures below $300^{\circ} \mathrm{C}$ [36-38]. However, in our case, textural relationships suggest that tetrahedrite-tennantite could be exsolution products formed during sub-solidus re-equilibration of pre-existing Ag-rich galena during the system cooling (as foreseen by [28]), and that these minerals become highly reactive in a supergene condition, where they can release their geochemical budget [23].

\section{Conclusions}

Ore deposits of the investigated Trento sites are not only characterized by common base metal sulfides, such as sphalerite, galena, and chalcopyrite, but also contain peculiar accessory minerals that host several trace elements. On the whole, geochemistry rules out the occurrence of a unique mineralization phase, and points to distinct events (plausibly related to the various magmatic phases that affected the area), each of which was characterized by a distinctive trace-element fingerprint. 
Noteworthy, the presence of many accessory minerals and the relative geochemical budget could induce geochemical risks, as toxic elements could be transferred to local soil and water.

Author Contributions: G.B., C.N., P.F., L.C. sampled the studied rocks and planned the research. C.M. supervised the analyses at the University of Ferrara. M.C. provided useful indication in the interpretation of the data and drawn the figures.

Funding: This research was funded by FAR2018 provided by the University of Ferrara to G.B.

Acknowledgments: The authors are grateful to the reviewers who provided suitable suggestions and indications for improving the current version of the manuscript.

Conflicts of Interest: The authors declare no conflict of interest.

\section{References}

1. Brusca, C.; Perna, G. Inquadramento e Genesi dei Giacimenti di Galena Argentifera del Monte Calisio (Trento). In Proceedings of the Atti del Convegno “II Monte Calisio e L'argento delle Alpi Dall'antichità al XVIII Secolo, Giacimenti, Storia e Rapporti con la Tradizione Mineraria Mitteleuropea“, Civezzano, Italy, 14-15 October; 1995; pp. 19-30.

2. Cook, N.J.; Ciobanu, C.L.; Pring, A.; Skinner, W.; Shimizu, M.; Danyushevsky, L.; Saini-Eidukat, B.; Melcher, F. Trace and minor elements in sphalerite: A LA-ICPMS study. Geochim. Cosmochim. Acta 2009, 73, 4761-4791. [CrossRef]

3. Cook, N.J.; Etschmann, B.; Ciobanu, C.L.; Geraki, K.; Howard, D.L.; Williams, T.; Rae, N.; Pring, A.; Chen, G.; Johannessen, B.; et al. Distribution and Substitution Mechanism of Ge in a Ge-(Fe)-Bearing Sphalerite. Minerals 2015, 5, 117-132. [CrossRef]

4. Cook, N.J.; Ciobanu, C.L.; George, L.; Zhu, Z.-Y.; Wade, B.; Ehrig, K. Trace Element Analysis of Minerals in Magmatic-Hydrothermal Ores by Laser Ablation Inductively-Coupled Plasma Mass Spectrometry: Approaches and Opportunities. Minerals 2016, 6, 111. [CrossRef]

5. Junge, M.; Oberthür, T.; Melcher, F. Cryptic variation of chromite chemistry, platinum-group-element and-mineral distribution in the UG-2 chromitite-An example from the Karee Mine, western Bushveld Complex, South Africa. Econ. Geol. 2014, 109, 795-810. [CrossRef]

6. Junge, M.; Wirth, R.; Oberthür, T.; Melcher, F.; Schreiber, A. Mineralogical siting of platinum-group elements in pentlandite from the Bushveld Complex, South Africa. Miner. Depos. 2015, 50, 41-54. [CrossRef]

7. Goldmann, S.; Junge, M.; Wirth, R.; Schreiber, A. Distribution of trace elements in sphalerite and arsenopyrite on the nanometre-scale-discrete phases versus solid solution. Eur. J. Mineral. 2018, 31, 325-333. [CrossRef]

8. Ye, L.; Cook, L.; Ciobanu, C.L.; Yuping, L.; Qian, Z.; Tiegeng, K.; Wei, G.; Yulong, L.; Danyushevskiy, L. Trace and minor elements in sphalerite from base metal deposits in South China: A LA-ICPMS study. Ore Geol. Rev. 2011, 39, 188-217. [CrossRef]

9. Sassi, F.P.; Cesare, B.; Mazzoli, C.; Peruzzo, L.; Sassi, R.; Spiess, R. The crystalline basements of the Italian eastern Alps: A review of the metamorphic features. Period. Di Mineral. 2004, 73, $23-42$.

10. Spiess, R.; Cesare, B.; Mazzoli, C.; Sassi, R.; Sassi, F.P. The crystalline basement of the Adria microplate in the eastern Alps: A review of the palaeostructural evolution from the Neoproterozoic to the Cenozoic. Rend. Lincei 2010, 21, 31-50. [CrossRef]

11. Rottura, A.; Bargossi, G.M.; Caggianelli, A.; Del Moro, A.; Visonà, D.; Tranne, C.A. Origin and significance of the Permian high-K calc-alkaline magmatism in the central-eastern Southern Alps. Italy. Lithos 1998, 45, 329-348. [CrossRef]

12. Willcock, M.A.W.; Cas, R.A.F.; Giordano, G.; Morelli, C. The eruption. pyroclastic flow behaviour. and caldera in-filling processes of the extremely large volume $\left(>1290 \mathrm{~km}^{3}\right)$. intra- to extra-caldera. Permian Ora (Ignimbrite) Formation. Southern Alps. Italy. J. Volcanol. Geotherm. Res. 2013, 265, 102-126. [CrossRef]

13. Bosellini, A.; Gianolla, P.; Stefani, M. The Triassic Carbonate Platforms of the Dolomites (Northern Italy): Their Evolution and Stratigraphic Framework. Mem. Di Sci. Geol. 2003, 54, 111-185.

14. Avanzini, M.; Bargossi, G.M.; Borsato, A.; Selli, L. Note illlustrative Della Carta Geologica d'Italia Alla Scala 1:50,000; ISPRA-Servizio Geologico d'Italia: Trento, Italy, 2010; p. 060. 
15. Bianchini, G.; Natali, C.; Shibata, T.; Yoshikawa, M. Basic Dykes Crosscutting the Crystalline Basement of Valsugana (Italy): New Evidence of Early Triassic Volcanism in the Southern Alps. Tectonics 2018, 37, 2080-2093. [CrossRef]

16. Nimis, P.; Omenetto, P.; Giunti, I.; Artioli, G.; Angelini, I. Lead isotope systematics in hydrothermal sulphide deposits from the centraleastern Southalpine (northern Italy). Eur. J. Mineral. 2012, 24, 23-37. [CrossRef]

17. Artioli, G.; Angelini, I.; Tecchiati, U.; Pedrotti, A. Eneolithic copper smelting slags in the Eastern Alps: Local patterns of metallurgical exploitation in the Copper Age. J. Archaeol. Sci. 2015, 63, 78-83. [CrossRef]

18. Murara, G. Le Mineralizzazioni a Solfuri Misti Nelle Vulcaniti Atesine, Formazione Andesitica, Dell'alta Val Fersina (Trentino). In Atti del Symposium Internazionale sui Giacimenti Minerari delle Alpi Atti del Symposium Internazionale sui Giacimenti Minerari delle Alpi; Regione Trentino Alto Adige e CCIA: Trento, Italy, 1966; Volume 2, pp. 471-493.

19. Barillari, A.; Jobstraibizer, P.G.; Omenetto, P. II Giacimento a Piombo, Zinco e Rame di Cinque Valli in Valsugana (Trentino). In Atti del Symposium Internazionale sui Giacimenti Minerari delle Alpi; Regione Trentino Alto Adige e CCIA: Trento, Italy, 1966; Volume 3, pp. 769-791.

20. Shiga, Y.; Urashima, Y. Isomorphous compounds; Galena Clausthalite, and altaite from the Kushikino gold-silver ore deposit, Japan-possible substitutional limits. Min. Geol. 1989, 39, 253-260.

21. Seryotkin, Y.V.; Pal'yanov, G.A.; Savva, N.E. Sulfur-selenium isomorphous substitution and morphotropic transition in the $\mathrm{Ag}_{3} \mathrm{Au}(\mathrm{Se}, \mathrm{S})_{2}$ series. Russ. Geol. Geophys. 2013, 54, 646-651. [CrossRef]

22. Bullock, L.A.; Perez, M.; Armstrong, J.G.; Parnell, J.; Still, J.; Feldmann, J. Selenium and tellurium resources in Kisgruva Proterozoic volcanogenic massive sulphide deposit (Norway). Ore Geol. Rev. 2018, 99, 411-424. [CrossRef]

23. Radková, A.B.; Jamieson, H.; Llinská-Voleková, B.; Majzlan, J.; Števko, M.; Chovan, M. Mineralogical controls on antimony and arsenic mobility during tetrahedrite-tennantite weathering at historic mine sites Špania Dolina-Piesky and L'ubietová-Svätodušná, Slovakia. Am. Mineral. 2017, 102, 1091-1100. (In Slovak)

24. Cheng, Y.; Spandler, C.; Kemp, A.; Mao, J.; Rusk, B.; Hu, Y.; Blake, K. Controls on cassiterite $\left(\mathrm{SnO}_{2}\right)$ crystallization: Evidence from cathodoluminescence, trace-element chemistry, and geochronology at the Gejiu Tin District. Am. Mineral. 2019, 104, 118-129. [CrossRef]

25. Pons, M.-L.; Debret, B.; Bouilhol, P.; Delacour, A.; Williams, H. Zinc isotope evidence for sulfate-rich fluid transfer across subduction zones. Nat. Commun. 2016, 7, 13794. [CrossRef] [PubMed]

26. Giuli, G.; Paris, E.; Wu, Z.; De Panfilis, S.; Pratesi, G.; Cipriani, G. 2005The Structural Role of Ag in Galena (PbS). A XANES Study. Phys. Scr. 2005, T115, 387-389. [CrossRef]

27. Pažout, R.; Sejkora, J.; Šrein, V. Ag-Pb-Sb Sulfosalts and Se-rich Mineralization of Anthony of Padua Mine near Poličany-Model Example of the Mineralization of Silver Lodes in the Historic Kutná Hora Ag-Pb Ore District, Czech Republic. Minerals 2019, 9, 430. [CrossRef]

28. Amcoff, O. Distribution of silver in massive sulfide ores. Miner. Depos. 1984, 19, 63-69. [CrossRef]

29. Chutas, N.I.; Kress, V.C.; Ghiorso, M.S.; Sack, R.O. A solution model for high-temperature PbS-AgSbS2-AgBiS2 galena. Am. Mineral. 2008, 93, 1630-1640. [CrossRef]

30. Sack, R.O.; Loucks, R. Thermodynamic properties of tetrahedrite-tennantites: Constraints on the interdependence of the $\mathrm{Ag} \leftrightarrow \mathrm{Cu} . \mathrm{Fe} \leftrightarrow \mathrm{Zn} . \quad \mathrm{Cu} \leftrightarrow \mathrm{Fe}$. and $\mathrm{As} \leftrightarrow \mathrm{Sb}$ exchange reactions. Am. Mineral. 1985, 70, 1270-1289.

31. Arlt, T.; Diamond, L.W. Composition of tetrahedrite-tennantite and 'schwazite' in the Schwaz silver mines. North Tyrol, Austria. Mineral. Mag. 1998, 62, 801-820. [CrossRef]

32. George, L.L.; Cook, N.J.; Ciobanu, C.L. Minor and trace elements in natural tetrahedrite-tennantite: Effects on element partitioning among base metal sulphides. Minerals 2017, 7, 17. [CrossRef]

33. Lynch, J.V.G. Large-scale hydrothermal zoning reflected in the tetrahedrite-freibergite solid solution. Keno hill Ag-Pb-Zn district, Yukon. Can. Mineral. 1989, 27, 383-400.

34. Sack, R.O.; Lynch, J.V.G.; Foit, F. Fahlore as a petrogenetic indicator: Keno Hill Ag-Pb-Zn District. Yukon. Canada. Mineral. Mag. 2003, 67, 1023-1038. [CrossRef]

35. Catchpole, H.; Kouzmanov, K.; Fontboté, L. Copper-excess stannoidite and tennantite-tetrahedrite as proxies for hydrothermal fluid evolution in a zoned cordilleran base metal district. Morococha. central Peru. Can. Mineral. 2012, 50, 719-743. [CrossRef]

36. Sack, R.O. Note on "large-scale hydrothermal zoning reflected in the tetrahedrite-freibergite solid solution. Keno Hill Ag-Pb-Zn district. Yukon” by J.V. Gregory Lynch. Can. Mineral. 2002, 40, 1717-1719. [CrossRef] 
37. Hernández, A.N.G.; Akasaka, M. Ag-rich tetrahedrite in the El Zancudo deposit, Colombia: Occurrence. chemical compositions and genetic temperatures. Resour. Geol. 2010, 218-233. [CrossRef]

38. Keim, M.F.; Walter, B.F.; Neumann, U.; Kreissl, S.; Bayerl, R.; Markl, G. Polyphase enrichment and redistribution processes in silver-rich mineral associations of the hydrothermal fluorite-barite-(Ag-Cu) Clara deposit. SW Germany. Miner. Depos. 2018, 54, 155-174. [CrossRef] 